\title{
Ownership advantages/disadvantages of Singapore transnational construction corporations
}

\author{
JAVIER C. CUERVO* and LOW SUI PHENG \\ School of Design Ë Environment, Department of Building, National University of Singapore, \\ 4 Architecture Drive, Singapore 117566
}

Received 3 April 2002; accepted 19 September 2002

\begin{abstract}
Expanding beyond Singapore's boundaries has been a source of increased business for Singapore transnational construction corporations (STCCs). This paper analyses the significance of ownership advantage and disadvantage factors of STCCs in pursuing their international construction business, relative to other ASEAN contractors and contractors from developed countries. Moreover, this study examines if these ownership factors do vary significantly according to firm specific contextual variables in the STCCs such as size, international age, multinationality and extent of specialization/diversification. Based on responses from 22 STCCs, this study has found that the most important ownership advantage factors of STCCs were identified as coming from: (1) information, knowledge, technology and R\&D capability; (2) the firm's name and reputation; and (3) management and organizational capability. Relative to established international contractors STCCs have a significant size disadvantage with reference to certain project types.
\end{abstract}

Keywords: Ownership advantages and disadvantages, Singapore transnational construction corporation, international construction

\section{Introduction}

The external economy of Singapore has developed significantly as the number and value of foreign investment and trade of Singapore-based corporations increased. The total direct investment of local-controlled corporations doubled from around $\$ \$ 20$ billion in 1994 to $\$ \$ 40$ billion in 1998 (Singapore Department of Statistics, 1997, 2000). The increased regionalization effort was likewise experienced in the construction industry until the mid-1997 financial crisis set in and negatively affected the economies of the Association of Southeast Asian Nations (ASEAN). Up to 1998, Singapore contractors had had increasing external construction activity in terms of foreign investments and export earnings from international projects. While construction exports registered a measly S\$1 18 million in 1984, for the six-year period from 1992 to 1997 , the export performance by Singapore contractors consistently hit the $\$ 1$ billion mark (CIDB, various issues; BCA, 1999).

*Author for correspondence. E-mail: bemp7001@nus.edu.sg
The aim of this paper is to analyse the significance and variation of ownership advantages and disadvantages underpinning the foreign value-added construction activities of Singapore transnational construction corporations (STCCs). Ownership advantages have a crucial role in the foreign value-added activities of transnational corporations (Hymer, 1976; Lall, 1993). Ownership advantages are derived from the firm's intangible assets such as management expertise, organizational capabilities, technology or a differentiated product (Hymer, 1976). The overseas expansion of industries from the USA, for example, was propelled by a combination of technology and product differentiation (Lall, 1993). Ownership advantages are especially necessary for a firm's initial foreign direct investment (Dunning, 1988a). These are reasons for focusing on ownership factors in this paper. Others have written on the ownership advantages of international contractors in the UK (Seymour, 1987; Mansfield, 1988). This paper contributes by empirically analysing the crucial role of ownership factors for the international construction of STCCs operating from Singapore - an open, land-scarce, high per-capita income economy in Asia. 
There are a number of economic factors and theories that explain the foreign investments and exports (i.e. foreign value-added activities) of corporations. The eclectic paradigm of international production developed by Dunning (1981, 1983, 1988a, 1990, 1995, 1997) is one framework that provides an explanation of the foreign value-added activities of transnational corporations (TNCs) and potential TNCs. The usefulness of the eclectic paradigm of international production is that it provides a framework for answers to the basic questions the why, where and how - of foreign value-added activities of firms. Initially referred to as an eclectic theory of international production (Dunning, 1977), the paradigm asserts that the foreign value-added activities of TNCs or potential TNCs are a consequence of obtaining advantages from three sources. First, the ownership (O) advantages of the corporation relative to competitors; second, the location (L) advantages of the foreign host country; and third, the internalization (I) advantages derived from the cross-border market of the corporation's tangible and intangible assets (Dunning, 1998a).

A number of criticisms on Dunning's eclectic paradigm of international production have been made since it was first presented in 1976 at the Nobel symposium held in Stockholm (Dunning, 1977). Lundgren (1977) noted the limited predicting power of the paradigm and suggested the inclusion of three structural determinants of international production (viz., country-specific, industry/ activity specific and firm/enterprise-specific). Cantwell (1991) proposed for a collective ownership advantage in lieu of the claimed overlap between ownership and internalization advantages. Dunning (1993) acknowledged the contribution of Itaki (1991) in explaining the nature and use of ownership advantages. Gray (1999) introduced managerial efficiency in place of internalization advantages by merging transaction asset ownership advantages with internalization advantages.

Although studies have been completed on the application of the eclectic paradigm of international production to better understand the foreign value-added activities of TNCs, there remains a lack of such studies in the domain of STCCs. The significance of the structure of the ownership factors of STCCs and potential STCCs will vary according to a number of contextual variables. First, the specific countries (i.e. home and host countries) involved in the foreign value-added activity. Second, the type of foreign value-added activities involved. Third, the firm-specific characteristics (e.g. age, size, multinationality and extent of specialization) of the corporation. Fourth, the reasons for undertaking the foreign direct investment (FDI) (Dunning, 1998a).

Although three factors (i.e. the OLI factors) form part of the eclectic paradigm of international production, due to the fundamental role of ownership factors in foreign direct investments, this paper will focus on analysing the ownership factors of STCCs as they undertake foreign value added construction-related activities. It is of note that Abdul Aziz (1995) emphasized on assessing the role of internalization factor for international contractors, whereas, Nachum (1999) focused on location and ownership factors of professional service firms, including construction.

Two research questions guide the development of this study (Dunning and Kundu, 1995):

(1) What ownership factors do managers with international construction experience of STCCs view as the most significant in engaging in foreign value-added construction-related activities in their major international construction market?

(2) Do the ownership factors viewed by managers of these STCCs vary significantly according to size, international age, multinationality and extent of specialization/diversification (i.e. firm specific contextual variables or FSCVs)?

\section{Ownership factors}

The ownership advantage factors of TNCs or potential TNCs are of two types: the asset-based and the transaction-based. The asset-based ownership advantage is the exclusive or privileged possession of countryspecific and firm-specific intangible and tangible assets, which gives the owner some proprietary advantage in the value-adding process of a particular product. On the other hand, the transaction-based ownership advantages reflect the ability of a corporation to coordinate, by administrative fiat, the separate but complementary activities better than other corporations of different ownership and the market (Dunning, 1985).

The asset-based ownership advantages coming from the home country and the corporation are especially important in the initial foreign entry. However, through time, the transaction-based ownership advantages become an increasingly important source of ownership advantages as the extent, form of multinationality and co-ordination of foreign value-added activities of the TNC increases (Dunning, 1998b, 1998c). The historical shift of importance of the transaction cost-based ownership advantages relative to the asset-based ownership advantages has been observed by Dunning (1988b). This shift of importance in the two types of ownership advantages of country's firms relative to its foreign competitors is likely to be strongly linked to the country's stage of economic development and degree of industrialization (Dunning, 1993). In particular, Dunning (1993) highlighted the growing importance of the transaction cost-based ownership advantages of a firm relative to its asset-based ownership advantages as its country's economy becomes developed. 
The position of Dunning (1998b, 1998c) is confirmed in an empirical study by Nachum (1999, p. 201), who observed that:

the impact of home countries on the competitiveness of firms is more important at the initial stages of the life cycle of a firm and it tends to lose some of its effect over time, as the firm matures and expands its international activity. At this stage, the impact of the foreign countries in which the firm operate increases somewhat, and as the firm becomes more involved with a particular foreign market, the impact of the latter tends to increase.

The factors that contribute to the ownership specific advantages of firms before they engage in FDI and those advantages which firms could acquire due to foreign value adding activities is clearly distinguished by Dunning (1988a, p. 5), who pointed out that:

it is the combination of the assets which the firm possesses prior to the act of FDI and those which it may acquire as a result of FDI, together with the entrepreneurship and judgemental capabilities of the main decision-takers, which comprise the competitive or ownership specific advantage of firms; and that these are necessary to explain, at least the initial act of international production.

The endogenous character of the ownership advantages of Dunning's eclectic paradigm of international production distinguishes it from internalization theory in explaining international production. The ownership (O-specific) variables are endogenous under the socio-institutional framework of 'hierarchical capitalism' as explained by Dunning (1995, p. 465-6), who argued that the 'eclectic paradigm is different from internalization theory in that it treats the competitive (so called O-specific) advantages of MNEs, apart from that which arise from the act of cross-border internalization, as endogenous rather than as exogenous variables. This means that the paradigm is not just concerned with answering the question of why firms engage in FDI, in preference to other modes of crossborder transactions. It is also concerned with why these firms possess unique resources and competencies relative to their competitors of other nationalities - and why they choose to use at least some of these advantages jointly with a portfolio of foreign-based immobile assets.'

\section{Research methodology}

The fieldwork part of this study was completed in mid2001. Responses from 22 STCCs, representing at least $75 \%$ of Singapore's total construction exports in 1997 and 1998 were used as the bases of the conclusions and findings. Information was captured by employing the questionnaire survey, interviews and archival of secondary sources of data. Following a pilot study, the respondents were asked to rate ownership factors on a five-point Likert scale that has been identified from the literature. The ranking of the ownership factors were subsequently determined using the mean importance rating (MIR) of the factors. The ranking of the ownership factors were assessed according to the most important factors and all the identified ownership factors as viewed by managers of STCCs according to a number of firm-specific contextual variables (FSCVs, e.g. age, size, multinationality and extent of specialization).

\section{Significance of ownership factors}

In order to determine the level of importance of the overall and individual ownership factors assessed by the managers of STCCs, the MIR is computed and tabulated to extract the ranking of each factor. The assessment of the ownership factors is done with reference to the major international construction market of the STCCs, as they compete with other ASEAN contractors and international contractors from developed countries (i.e. non-ASEAN contractors).

The first research sub question reads 'What ownership advantage factors do managers with international experience working in STCCs consider as the most significant factors in engaging in foreign value-added constructionrelated activities in their major international construction market?' Table 1 (section A, columns 2 and 3) shows that when compared with other ASEAN contractors, managers of STCCs ranked three intangible asset advantages as most significant when competing in their major international construction market. These advantages are, according to their ranking: first, information, knowledge, technology and R\&D capability; second, the firm's name and reputation; and third, management and organizational capability.

Through technological innovations, STCCs are able to differentiate their construction services and in the process develop a track record and thereby establish a good reputation and name in the industry. However, the enabling factor that is able to bring out the intangible asset advantages is the management capabilities of the STCC.

An executive director from Company $\mathrm{D}$, who has been in the industry for more than 10 years, emphasized that 'clients engaged their company because of their superior technological know-how and relevant experience'. Likewise, an assistant vice-president from a Government Linked Company or GLC (Company E), pointed out that 'experience and track record is supported by our R\&D'. With regard to the importance of preserving the good name of the company, a director with Company B with 11 years of international construction experience noted: 'I think in our company we honour to complete the project 
Table 1 Ownership advantage factors viewed by managers of STCCs

\begin{tabular}{|c|c|c|c|c|}
\hline & \multicolumn{2}{|c|}{$\begin{array}{c}\text { ASEAN } \\
\text { contractors }\end{array}$} & \multicolumn{2}{|c|}{$\begin{array}{c}\text { Non-ASEAN } \\
\text { contractors }\end{array}$} \\
\hline & MIR & Rank & MIR & Rank \\
\hline \multicolumn{5}{|l|}{ A. Intangible asset advantages } \\
\hline Information, knowledge, technology and $\mathrm{R} \& \mathrm{D}$ capability & 3.818 & 1 & 2.857 & 6 \\
\hline Business development capability & 3.667 & 5 & 2.900 & 3 \\
\hline Management and organizational capability & 3.714 & 3 & 2.895 & 5 \\
\hline Resource access (including project finance) capability & 3.364 & 8 & 2.500 & 9 \\
\hline Personnel/Human resource management capability & 3.409 & 6 & 3.000 & 2 \\
\hline Industrial structure capability & 3.273 & 9 & 2.750 & 8 \\
\hline Firm-level and stakeholder's networking capability & 3.409 & 7 & 2.900 & 4 \\
\hline Multinationality/International experience capability & 3.682 & 4 & 2.800 & 7 \\
\hline Firm's name and reputation & 3.810 & 2 & 3.100 & 1 \\
\hline \multicolumn{5}{|l|}{ B. Transactional E organizational advantages } \\
\hline Personal relationship advantages & 3.227 & 4 & 2.950 & 6 \\
\hline Flexible production and work systems & 3.318 & 3 & 3.000 & 4 \\
\hline Stakeholder's commitment to client's needs & 3.500 & 1 & 3.300 & 1 \\
\hline Organizational competence & 3.364 & 2 & 3.150 & 2 \\
\hline Common governance of activities within the supply chain & 2.810 & 7 & 3.150 & 3 \\
\hline Diversification benefits & 2.909 & 6 & 3.000 & 5 \\
\hline Size of firm advantage & 2.954 & 5 & 2.800 & 7 \\
\hline Home government support and assistance & 2.500 & 8 & 2.650 & 8 \\
\hline \multicolumn{5}{|l|}{ C. Country-specific ownership advantages } \\
\hline Ample supply of skilled and productive workers & 3.182 & 5 & 2.800 & 7 \\
\hline Ample supply of unskilled workers & 2.591 & 10 & 2.350 & 10 \\
\hline Facility with languages for international business communications & 3.591 & 1 & 3.000 & 4 \\
\hline Strengthening of home currency & 3.136 & 6 & 3.050 & 3 \\
\hline Availability of a cheap source of capital/funds/credit & 2.773 & 8 & 2.600 & 8 \\
\hline Technological infrastructure & 3.545 & 2 & 2.950 & 5 \\
\hline Comparative advantage of country's mobile resources & 3.136 & 7 & 2.900 & 6 \\
\hline An intensive use of the country's abundant resource & 2.636 & 9 & 2.500 & 9 \\
\hline Physical infrastructure (in general) & 3.364 & 4 & 3.053 & 2 \\
\hline Legal and property rights are protected & 3.455 & 3 & 3.263 & 1 \\
\hline
\end{tabular}

even how difficult the task is. Even when the government [of the host country] is in turbulence we will still honour our project. We have created a very good reputation with some foreign governments. They also recognize that we are those contractors that don't leave the country when there is a difficult period involved'. A commercial manager of a private listed STCC (Company R) put it simply: 'it is very important that to generate profit, we need to manage the project in terms of time and costs. This is very important'.

In relation to non-ASEAN contractors (e.g. Korean, Japanese, American or European) in the ASEAN region outside Singapore, the managers of STCCs viewed their three most important intangible asset advantages as coming from their firm's name and reputation; human resource management capabilities; and business development capabilities (Table 1, section A, columns 4 and 5). The finding is not surprising since some STCCs would be known in the region for having established a track record in a certain area of specialization. Moreover, STCCs have greater familiarity with the people of the region in terms of their language, history, culture and ways of doing business compared with contractors from non-ASEAN countries.

In terms of the most highly ranked transactional and organizational asset advantage (Table 1, section B, columns 2, 3, 4 and 5), managers of STCCs viewed these as coming from their stakeholder's commitment to client's needs and to their organizational competence in managing their domestic and foreign assets, relative to both ASEAN and non-ASEAN contractors.

A senior manager with a GLC (Company G) involved in design and build procurement systems comprehensively explained the value of maintaining the stakeholder's commitment to client's needs well beyond the construction of a physical product. He noted that:

our objectives is not of being a developer [of constructed facilities] but really a total solutions provider. And as a total solutions provider means we have to make sure that they are well taken care of. That the facilities are well maintained and I think we have the 
better product knowledge than their maintenance staff because we have created the product. And therefore I think if we are able to add value by staying home with them; helping them to maintain the serviceability or to upgrade in the future or to extend, I think we are in a much better position to provide them. And therefore, in a sense, the shareholder's commitment is beyond one of P\&L [profit and loss], is beyond one of quality delivery; but one of good commitment of partnership building. (...) And therefore, unless stakeholders are committed and we truly understand the values and the networks we are building. The partnership we are building, which is again building partnerships through partnerships we are building an upside to our business in countries that we operate. And therefore, this aspect of stakeholder's commitment is extremely important.

Table 1 (section C, columns 2 and 3) shows, in general, that managers of STCCs viewed their highest ranked country-specific ownership advantages in relation to other ASEAN contractors to be their facility with languages for international business communications. The second highest ranked country-specific ownership advantage is that STCCs can depend on Singapore's superior technological infrastructure.

An assistant vice-president of Company $\mathrm{E}$ who has 15 years of international construction experience noted that as far as operating in the ASEAN region is concerned:

Singaporeans speak Malay for the Malaysia, Indonesia and Brunei market. There are no language barriers there. With regard to Vietnam and Cambodia, we are in the same footing as the Japanese and Koreans. The command of English by the Japanese and Koreans is limited to few management staff, and not the entire organization, unlike the Singaporean organization.

Likewise, a marketing manager of Company $\mathrm{H}$ noted 'feedback from project engineers stating that language is a very important factor especially during project execution of large infrastructure projects in overseas markets.'

Table 1 (section C, columns 4 and 5) shows that managers of STCCs viewed ownership advantages deriving from Singapore relative to non-ASEAN contractors as coming from the protection of their legal and property rights. This concerns the professional legal support available in Singapore for writing and enforcing international construction contracts; and to the protection of property rights of STCCs in Singapore.

One of the most senior directors (Company A) interviewed clearly pointed out the importance of securing their rights when operating construction works overseas: 'We would like to go to a country where our rights are protected. We do not want to go to a country that will be prejudiced against our rights. This is very important to us. In case there will be any dispute. We want the dispute to be fair to all sides. This is important to us'.

Managers of STCCs viewed their greatest ownership disadvantage as the reducing demand for construction services in Singapore. The two next important ownership disadvantages of STCCs compared to contractors from other ASEAN countries is the latter's lower costs, relative to STCCs and the other ASEAN contractors having a better knowledge of their country and clients (see Table 2).

In order to sustain a track record, it is imperative for STCCs to maintain a continuous source of large projects in Singapore. The reduction of demand for construction projects coupled with the intense competition from international contractors is a significant source of ownership disadvantage for STCCs. The Singapore construction market is highly competitive where margins are thin and international contractors dominate large projects.

Table 2 Ownership disadvantage factors viewed by managers of STCCs

\begin{tabular}{|c|c|c|c|c|}
\hline \multirow[t]{2}{*}{ Ownership disadvantage factors } & \multicolumn{2}{|c|}{$\begin{array}{c}\text { ASEAN } \\
\text { contractors }\end{array}$} & \multicolumn{2}{|c|}{$\begin{array}{c}\text { Non-ASEAN } \\
\text { contractors }\end{array}$} \\
\hline & MIR & Rank & MIR & Rank \\
\hline Protectionist government policies of host countries & 3.273 & 6 & 3.190 & 5 \\
\hline Lower costs of other country's contractors & 3.429 & 2 & 3.105 & 8 \\
\hline Competitors have better knowledge of their country and clients & 3.364 & 3 & 3.200 & 3 \\
\hline Reducing home market demand & 3.571 & 1 & 3.316 & 2 \\
\hline Better tax policies for other foreign contractors & 2.900 & 11 & 2.647 & 12 \\
\hline The practice of multi-level subcontracting reduces control on quality & 2.955 & 8 & 2.842 & 10 \\
\hline Little or less government support compared with competitors & 2.955 & 9 & 3.200 & 4 \\
\hline Foreign contractors have a cheaper source of project finance & 3.227 & 7 & 3.143 & 6 \\
\hline Client's favour ('bias') for multinational contractors & 3.364 & 4 & 3.143 & 7 \\
\hline Poorer quality of materials and supplies in home country & 2.429 & 14 & 2.500 & 13 \\
\hline Communication and language problem & 2.762 & 12 & 2.450 & 14 \\
\hline Smaller size of Singaporean firm & 3.286 & 5 & 3.350 & 1 \\
\hline Lack of technological ability & 2.727 & 13 & 3.048 & 9 \\
\hline A lack of national collaboration between domestic firms & 2.955 & 10 & 2.762 & 11 \\
\hline
\end{tabular}


Regarding the ownership disadvantage of STCCs relative to other ASEAN contractors, an executive director (Company C) with 10 years of international construction experience noted that in countries like China, they don't need much quality and technology. Speed of works is also not an important point for them. They have lots of employment, and so they can afford to take more time, at lower costs. Whereas, for Singaporean construction companies time, technology and quality are important'. Relative to international construction companies from developed countries, managers viewed their greatest ownership disadvantage to be the relatively smaller size of STCCs (see Table 2).

The second sub question is: 'How does the ownership factors vary in significance according to firm specific contextual variables (or FSCVs)?' The question is answered by way of two methodologies: (a) with regard to the most important ownership factor according to relevant firm specific contextual variables as determined by the highest MIR given to the ownership factors; (b) with regard to whether there is any significant variation for all the ownership factors according to the firm specific contextual variables. In order to determine if there is any significant variation in the assessment of STCCs for all the ownership factors according to firm specific contextual variables, a hypothesis test of the Spearman's rho correlation coefficient is conducted.

\section{Variation in the most important ownership factor}

The discussion in the following tables will be restricted to the more crucial findings with reference to the firm specific contextual variables of this study.

\section{By size (number of employees)}

Table 3 shows that the 13 STCCs with less than 200 employees viewed their most important intangible asset ownership advantage relative to other ASEAN contractors as their better information, knowledge, technology and $\mathrm{R} \& \mathrm{D}$ capabilities. These sources of innovation overcome their apparent disability in terms of their relatively smaller organizational size. With regard to international contractors (non-ASEAN), these STCCs identified their greatest ownership intangible asset advantage as coming from their human resource management capabilities.

The most important transaction asset ownership advantage of the smaller STCCs in relation to both ASEAN and non-ASEAN contractors is that of their stakeholder's commitment to client's needs. However, this factor was viewed as more significant, based on a higher MIR, relative to other ASEAN contractors (Table 3, section $\mathrm{B}$ ).
Table 3 (section C, columns 6 and 7) shows that the facility with languages for international business communications and the technological infrastructure were viewed by these smaller STCCs as two of the most important ownership advantages derived from Singapore when compared with other ASEAN contractors. However, the smallest contractors from Singapore with international projects viewed the protection of their legal and property rights as their most important country-specific ownership advantage compared with international contractors from non-ASEAN countries.

The 13 STCCs with less than 200 employees viewed the protectionist government policies of host countries as their main ownership disadvantage relative to other ASEAN contractors and more developed international contractors (Table 3, Ownership Disadvantages, columns 6 and 7). It was also noted as a disadvantage for STCCs that clients in other ASEAN countries also tended to favour or have a bias for international contractors from developed countries.

\section{By age (number of years of international construction experience)}

The three STCCs with more than 20 years of international construction experience identified having a good name and reputation as their most important intangible asset advantage relative to other ASEAN contractors. Having a good name means being able to compete on the basis of quality service and not just on price (i.e. costbased competition). Relative to international contractors from developed countries these STCCs viewed their greatest intangible asset ownership advantage to be their organizational management and human resource management capabilities (see Table 4).

STCCs with the longest experience in international construction viewed their relatively larger size, in terms of the number of employees, compared with other ASEAN contractors as their most important transactional ownership advantage. However, relative to non-ASEAN contractors, it was both their stakeholder's commitment to client's needs, and their organizational competence being their most important transactional ownership advantage (Table 4, section B, columns 6 and 7). Table 4 (section C, columns 6 and 7) shows that STCCs with more than 20 years international construction experience viewed the technological infrastructure available in Singapore as their greatest source of ownership advantage compared with their ASEAN counterparts. However, it was the physical infrastructure in Singapore, in general; the comparative advantage of their mobile resources; and the protection of their legal and property rights that figures as their most important country-specific ownership advantage relative to more developed international contractors. 
Table 3 The most important ownership factors according to MIR, as viewed by managers of STCCs, by size (number of employees), total $n=22$

\begin{tabular}{|c|c|c|c|c|c|c|}
\hline \multirow[t]{2}{*}{ Ownership factors } & \multicolumn{2}{|c|}{$\begin{array}{l}\text { More than } 500 \\
\qquad(n=3)\end{array}$} & \multicolumn{2}{|c|}{$\begin{array}{l}200 \text { to } 500 \\
\quad(n=6)\end{array}$} & \multicolumn{2}{|c|}{$\begin{array}{l}\text { Less than } 200 \\
\quad(n=13)\end{array}$} \\
\hline & ASEAN & $\begin{array}{l}\text { Non- } \\
\text { ASEAN }\end{array}$ & ASEAN & $\begin{array}{l}\text { Non- } \\
\text { ASEAN }\end{array}$ & ASEAN & $\begin{array}{l}\text { Non- } \\
\text { ASEAN }\end{array}$ \\
\hline \multicolumn{7}{|l|}{ Ownership advantages } \\
\hline A. Intangible asset advantages & 4.667 & & 4.333 & & & \\
\hline Firm's name and reputation & & 3.333 & & & 3.846 & \\
\hline \multicolumn{7}{|l|}{$\begin{array}{l}\text { Information, knowledge, technology and } \\
\text { R\&D capability }\end{array}$} \\
\hline Firm-level and stakeholder's networking capability & & & & 4.167 & & \\
\hline Personnel/Human resource management capability & & & & & & 2.833 \\
\hline B. Transactional \& organizational advantages & 4.000 & & & & & \\
\hline Organizational competence & & & 3.833 & 4.167 & 3.462 & \\
\hline Stakeholder's commitment to client's needs & & & 3.833 & & & 3.083 \\
\hline \multicolumn{7}{|l|}{ Size of firm advantage } \\
\hline $\begin{array}{l}\text { Common governance of activities within the } \\
\text { supply chain }\end{array}$ & & 3.000 & & & & \\
\hline Home government support and assistance & & 3.000 & & & & \\
\hline C. Country-specific ownership advantages & 4.000 & & & & 3.538 & \\
\hline Facility with languages for international business & & 3.500 & & & & \\
\hline communications & & & 4.000 & & 3.538 & \\
\hline Technological infrastructure & & & 4.000 & & & \\
\hline Legal and property rights are protected & & & & 3.667 & & 3.091 \\
\hline Strengthening of home currency & & 3.500 & & & & \\
\hline Comparative advantage of country's mobile resources & & 3.500 & & & & \\
\hline Physical infrastructure (in general) & & 3.500 & & & & \\
\hline Ownership disadvantages & 4.000 & & & & & \\
\hline Reducing home market demand & & 4.000 & 4.000 & & & \\
\hline $\begin{array}{l}\text { Foreign contractors have a cheaper source of project } \\
\text { finance }\end{array}$ & & & & 4.167 & 3.538 & \\
\hline Protectionist government policies of host countries & & & & & 3.538 & 3.417 \\
\hline Client's favour ('bias') for multinational contractors & & & & & & \\
\hline $\begin{array}{l}\text { Competitors have better knowledge of their country } \\
\text { and clients }\end{array}$ & & 4.000 & & & & \\
\hline
\end{tabular}

Note: MIR is 'Mean Importance Rating'.

STCCs with more than 20 years international construction experience viewed the reducing construction market demand in Singapore and the lower costs of other ASEAN contractors as their greatest ownership disadvantage. However, the lower costs of project finance available to international contractors from some countries were identified as the relative disadvantage of STCCs (Table 4, Ownership Disadvantages).

A general manager of a private company (Company L) involved in civil engineering works observed that 'contractors from Japan and Belgium have a better source of project finance. The government or multinationals absorb their losses. They tender for projects on zero per cent profit margins. Moreover, in the case of Singapore construction firms, they have to cough up their own performance bonds, whereas for the Japanese contractors this is not a problem or difficulty in tendering'.

\section{By multinationality (number of permanent offices overseas)}

Table 5 (section A) shows that STCCs with the most number of permanent offices overseas viewed their most important intangible asset ownership advantage compared to other ASEAN contractors as having established a good name and reputation in the industry. STCCs with the most number of overseas permanent offices viewed their organizational competence and size as their most important transactional asset ownership advantage compared with other ASEAN contractors (Table 5, section B). The facility with languages for international business was viewed by the most international STCCs as their main source of country-specific ownership advantages when compared with other ASEAN contractors and non-ASEAN contractors in the region (Table 5, section C). Table 5 
Table 4 The most important ownership factors according to MIR, as viewed by managers of STCCs, by age (years of international construction experience), total $n=20$

\begin{tabular}{|c|c|c|c|c|c|c|}
\hline \multirow[t]{2}{*}{ Ownership factors } & \multicolumn{2}{|c|}{$\begin{array}{c}1-10 \text { years } \\
(n=9)\end{array}$} & \multicolumn{2}{|c|}{$\begin{array}{c}11-20 \text { years } \\
(n=8)\end{array}$} & \multicolumn{2}{|c|}{$\begin{array}{l}\text { More than } 20 \\
\text { years }(n=3)\end{array}$} \\
\hline & ASEAN & $\begin{array}{c}\text { Non- } \\
\text { ASEAN }\end{array}$ & ASEAN & $\begin{array}{l}\text { Non- } \\
\text { ASEAN }\end{array}$ & ASEAN & $\begin{array}{l}\text { Non- } \\
\text { ASEAN }\end{array}$ \\
\hline \multicolumn{7}{|l|}{ Ownership advantages } \\
\hline A. Intangible asset advantages & 3.889 & & & & & \\
\hline $\begin{array}{l}\text { Information, knowledge, technology and R\&D } \\
\text { capability }\end{array}$ & & & 3.857 & & & \\
\hline Management and organizational capability & & & & & 4.667 & 4.000 \\
\hline Firm's name and reputation & & & & 3.167 & & \\
\hline Business development capability & & 3.000 & & & & \\
\hline Personnel/human resource management capability & & & & & & 4.000 \\
\hline B. Transactional \& Organizational advantages & 3.333 & & 3.625 & & & \\
\hline Personal relationship advantages & 3.333 & & 3.625 & & & \\
\hline Flexible production and work systems & 3.333 & & & & & \\
\hline $\begin{array}{l}\text { Stakeholder's commitment to client's needs } \\
\text { Size of firm advantage }\end{array}$ & & 3.333 & & & 4.667 & 4.000 \\
\hline Organizational competence & & & & 3.000 & & 4.000 \\
\hline Common governance of activities within the supply chain & & & & 3.000 & & \\
\hline C. Country-specific ownership advantages & 3.667 & & & & 4.000 & \\
\hline Technological infrastructure & & & 4.000 & & & \\
\hline \multicolumn{7}{|l|}{$\begin{array}{l}\text { Facility with languages for international business } \\
\text { communications }\end{array}$} \\
\hline Legal and property rights are protected & & 3.111 & & & & 3.667 \\
\hline Physical infrastructure (in general) & & & & 3.500 & & 3.667 \\
\hline Comparative advantage of country's mobile resources & & & & & & 3.667 \\
\hline Ownership Disadvantages & & & & & 4.000 & \\
\hline Reducing home market demand & 3.556 & & & & & \\
\hline $\begin{array}{l}\text { Little or less home government support compared with } \\
\text { competitors }\end{array}$ & & & 3.875 & & & \\
\hline Client's favour ('bias') for multinational contractors & & & & & 4.000 & \\
\hline Lower costs of other country's contractors & & & & & 4.000 & \\
\hline $\begin{array}{l}\text { Foreign contractors have a cheaper source of project } \\
\text { finance }\end{array}$ & & & & & & 4.000 \\
\hline Smaller size of Singaporean firm & & 3.875 & & & & \\
\hline Protectionist government policies of host countries & & & & 3.571 & & \\
\hline
\end{tabular}

Note: MIR is 'Mean Importance Rating'.

(ownership disadvantages) shows that the lower costs of other ASEAN contractors was the most significant ownership disadvantage for STCCs. However, when compared with more developed international contractors, it was the STCCs' lack of technological ability that figured as their main ownership disadvantage factor.

\section{By specialized or diversified STCCs}

Specialized and diversified STCCs viewed their most important intangible asset ownership advantages quite differently relative to other ASEAN contractors and nonASEAN contractors (see Table 6, section A). Relative to other ASEAN contractors, the specialized STCCs identified their management capabilities as their supreme source of ownership advantage, whereas the diversified
STCCs based their ownership advantage as coming from their more advanced technology. With regard to nonASEAN contractors, specialized STCCs viewed their human resource management capabilities as their most important intangible asset ownership advantage. The diversified STCCs named their reputation-track record - amongst clients in the region (i.e. ASEAN and China) as their most important intangible asset ownership advantage compared with non-ASEAN contractors.

Specialized STCCs viewed organizational capabil- ities as their source of transactional asset ownership advantages compared with other ASEAN contractors, whereas the diversified STCCs pointed out that their stakeholder's commitment to client's needs was their source of ownership advantages relative to non-ASEAN contractors in the ASEAN region and China (Table 6, section B). 
Table 5 The most important ownership factors according to MIR, as viewed by managers of STCCs, by number of permanent offices overseas, total $n=22$

\begin{tabular}{|c|c|c|c|c|c|c|}
\hline \multirow[t]{2}{*}{ Ownership factors } & \multicolumn{2}{|c|}{$\begin{array}{l}\text { More than } 10 \\
\quad(n=2)\end{array}$} & \multicolumn{2}{|c|}{$\begin{array}{l}6 \text { to } 10 \\
(n=3)\end{array}$} & \multicolumn{2}{|c|}{$\begin{array}{c}1 \text { to } 5 \\
(n=17)\end{array}$} \\
\hline & ASEAN & $\begin{array}{c}\text { Non- } \\
\text { ASEAN }\end{array}$ & ASEAN & $\begin{array}{c}\text { Non- } \\
\text { ASEAN }\end{array}$ & ASEAN & $\begin{array}{c}\text { Non- } \\
\text { ASEAN }\end{array}$ \\
\hline \multicolumn{7}{|l|}{ Ownership advantages } \\
\hline A. Intangible asset advantages & 4.500 & & 4.667 & & & \\
\hline Firm's name and reputation & & 2.500 & & 5.000 & 3.938 & \\
\hline Business development capability & & 2.500 & & & & 3.000 \\
\hline Management and organizational capability & & 2.500 & & 5.000 & & \\
\hline Resource access (including project finance) capability & & 2.500 & & & & \\
\hline Personnel/human resource management capability & & 2.500 & & & & \\
\hline Industrial structure capability & & 2.500 & & & & \\
\hline Information, knowledge, technology and $R \& D$ capability & & & & 5.000 & & \\
\hline Firm-level and stakeholder's networking capability & & & & 5.000 & & \\
\hline Multinationality/international experience capability & & & & 5.000 & & \\
\hline B. Transactional \& Organizational advantages & 4.000 & & 4.000 & & & \\
\hline Organizational competence & 4.000 & & & 5.000 & & \\
\hline Size of firm advantage & & & & 5.000 & 3.529 & \\
\hline Stakeholder's commitment to client's needs & & & & 5.000 & & 3.188 \\
\hline Common governance of activities within the supply chain & & 3.000 & & & & \\
\hline Home government support and assistance & & 3.000 & & & & \\
\hline Personal relationship advantages & & & & & & 3.188 \\
\hline C. Country-specific ownership advantages & 4.500 & & & & & \\
\hline $\begin{array}{l}\text { Facility with languages for international business } \\
\text { communications }\end{array}$ & & 3.500 & 3.667 & & & \\
\hline Technological infrastructure & & & & 5.000 & 3.647 & \\
\hline Legal and property rights are protected & & & & & & 3.133 \\
\hline Strengthening of home currency & & 3.500 & & & & \\
\hline Comparative advantage of country's mobile resources & & 3.500 & & & & \\
\hline Physical infrastructure (in general) & & 3.500 & & & & \\
\hline Ownership Disadvantages & 4.000 & & & & & \\
\hline Lower costs of other country's contractors & & & 3.667 & & 3.563 & \\
\hline Reducing home market demand & & & & 4.000 & & \\
\hline Lack of technological ability & & 4.500 & & & & \\
\hline Smaller size of Singaporean firm & & & & & & 3.333 \\
\hline
\end{tabular}

Note: MIR is 'Mean Importance Rating'.

The views of managers from specialized STCCs is that their most important country-specific ownership advantages relative to other ASEAN contractors was their greater facility with languages for international business communications in the ASEAN region and China. On the other hand, diversified STCCs saw the technological infrastructure in Singapore as the basis of their relative ownership advantage compared with other ASEAN contractors. Compared with non-ASEAN contractors, specialized STCCs viewed Singapore's physical infrastructure to be their source of ownership advantage, whereas the diversified STCCs thought it to be the effective protection of their legal and property rights (Table 6, section C).

Specialized STCCs identified the reducing construction demand in Singapore relative to other ASEAN countries as the main source of ownership disadvantage for them compared with other ASEAN contractors. Surprisingly, the lower costs of non-ASEAN contractors relative to specialized STCCs were viewed as the most important ownership disadvantage factor of specialized STCCs. Diversified STCCs however pointed out to their relatively smaller size compared with non-ASEAN contractors as their greatest liability (Table 6, ownership disadvantages).

\section{Variation in all ownership factors}

The following question is asked: 'Is it possible that the correlation between the ranking of all ownership factors viewed by managers of STCCs vis-à-vis ASEAN contractors and non-ASEAN contractors differed significantly according to firm-specific contextual variables?' To 
Table 6 The most important ownership factors according to MIR, as viewed by managers of STCCs, by specialized or diversified type, total $n=22$

\begin{tabular}{|c|c|c|c|c|}
\hline \multirow[t]{2}{*}{ Ownership factors } & \multicolumn{2}{|c|}{ Specialized $(n=8)$} & \multicolumn{2}{|c|}{ Diversified $(n=14)$} \\
\hline & ASEAN & Non-ASEAN & ASEAN & Non-ASEAN \\
\hline \multicolumn{5}{|l|}{ Ownership advantages } \\
\hline \multicolumn{5}{|l|}{ A. Intangible asset advantages } \\
\hline Management and organizational capability & 4.000 & & & \\
\hline Information, knowledge, technology and $\mathrm{R} \& \mathrm{D}$ capability & & & 4.071 & \\
\hline Personnel/human resource management capability & & 3.375 & & \\
\hline Firm's name and reputation & & & & 3.385 \\
\hline \multicolumn{5}{|l|}{ B. Transactional \& Organizational advantages } \\
\hline Flexible production and work systems & 3.625 & & & \\
\hline Stakeholder's commitment to client's needs & 3.625 & & 3.429 & 3.333 \\
\hline Organizational competence & 3.625 & 3.500 & & \\
\hline \multicolumn{5}{|l|}{ C. Country-specific ownership advantages } \\
\hline Facility with languages for international business communications & 3.875 & & & \\
\hline Technological infrastructure & & & 3.500 & \\
\hline Physical infrastructure (in general) & & 3.375 & & \\
\hline Legal and property rights are protected & & & & 3.333 \\
\hline Ownership Disadvantages & & & & \\
\hline Reducing home market demand & 3.750 & & & \\
\hline Smaller size of Singaporean firm & & & 3.538 & 3.667 \\
\hline Lower costs of other country's contractors & & 3.375 & & \\
\hline
\end{tabular}

Note: MIR is 'Mean Importance Rating'.

answer this question two steps are required. First, the Spearman's coefficient of rank correlation $\left(R_{S}\right)$ is computed for a pair of each type of firm-specific contextual variable (e.g. between specialist STCCs and diversified STCCs). ${ }^{1} R_{S}$ is used since the analysis concerns the relationship between two sets of ranked ordinal-level data. The second step is to conduct a test of the significance of $R_{S}$. Testing the significance of the Spearman rank correlation coefficient is to be carried out for the null hypothesis of no association between a pair of random variables, given its distribution under that hypothesis is known. The resulting test would be nonparametric although such a correlation measure is not susceptible to serious influence by extreme values. As such, conclusions about the rank correlation may well be obtained without an assumption of population normality. The conclusions can therefore be based for a very general population distribution through the use of rank ordinal data (Newbold, 1991). Furthermore, the Spearman coefficient of rank correlation is an appropriate way of testing the strength of monotonic relationships between a pair of random variables without being concerned of whether a linear relationship exists or not (Conover and Iman, 1983). The following directional null hypothesis $\left(\mathrm{H}_{\mathrm{o}}\right)$ and alternate hypothesis $\left(\mathrm{H}_{1}\right)$ are specified:

$\mathrm{H}_{\mathrm{o}}$ : The Spearman's coefficient of rank correlation of the MIR of the views of managers of STCCs of a pair of each type of firm-specific contextual variables (FSCV) relative to ASEAN or non-ASEAN contractors is equal to zero. Or alternatively, $\mathrm{H}_{\mathrm{o}}: \mathrm{R}_{\mathrm{S}}\left(\mathrm{FSCV}_{\mathrm{ijk}}\right)=0$, where $\mathrm{i}$ is the type of firm-specific contextual variable; and $\mathrm{j}$ is the firm-specific contextual variable and $\mathrm{k}$ is the origin of the contractor (i.e. ASEAN or non-ASEAN contractors).

$\mathrm{H}_{1}$ : The Spearman's coefficient of rank correlation of the MIR of the views of managers of STCCs of a pair of each type of firm-specific contextual variables (FSCV) relative to ASEAN or non-ASEAN contractors is greater than zero. Or alternatively, $\mathrm{H}_{1}$ : $\mathrm{R}_{\mathrm{S}}$ $\left(\mathrm{FSCV}_{\mathrm{ijk}}\right)>0$, where $\mathrm{i}$ is the type of firm-specific contextual variable; and $j$ is the firm-specific contextual variable and $\mathrm{k}$ is the origin of the contractor (i.e. ASEAN or non-ASEAN contractors).

The decision rule is to reject the null hypotheses if the computed t-statistic is greater than the critical t-statistic at $1 \%$ and $5 \%$ level of significance, for a one-tailed test with $n-2$ degrees of freedom, for a sample of 10 or more (Mason et al., 1999). A one-tailed test is used as the alternate hypothesis is directional (Tan, 1995).

Rejecting the null hypothesis in the context of this study would mean that there is positive or negative correlation between the ranks given by a pair of two types of FSCVs as identified by managers of STCCs vis-à-vis ASEAN or non-ASEAN contractors. For example, the rejection of a null hypothesis means that there is positive or negative correlation between the ranks of all ownership advantages given by specialized STCCs and those given by diversified STCCs vis-à-vis ASEAN contractors. On the other hand, the non-rejection of the null hypothesis in this case 
Table 7 Test of significance of variation in ranking of all ownership factors, Test of Hypothesis for size of firm, $H_{0}$ : $R_{S}$ $\left(\mathrm{FSCV}_{\mathrm{ijk}}\right)=0$, Where $\mathrm{i}=($ Large, Medium, Small STCC $) ; \mathrm{j}=($ size of firm $) ; \mathrm{k}=($ ASEAN or Non-ASEAN $)$

\begin{tabular}{|c|c|c|c|c|c|c|c|}
\hline \multirow{2}{*}{ Ownership factors } & \multirow[t]{2}{*}{$n$} & \multicolumn{3}{|c|}{ ASEAN contractors } & \multicolumn{3}{|c|}{ Non-ASEAN contractors } \\
\hline & & $\mathrm{R}_{\mathrm{S}}$ & Reject $\mathrm{H}_{0}$ ? & Significance level & $\mathrm{RS}_{\mathrm{S}}$ & Reject $\mathrm{H}_{0}$ ? & Significance level \\
\hline Ownership advantages & 27 & & & & & & \\
\hline Large and small & & .442 & Yes & $.05(2.464)$ & .187 & No & Ns \\
\hline Large and medium & & .471 & Yes & $.01(2.670)$ & -.340 & Yes & $.05(-1.808)$ \\
\hline Medium and small & & .477 & Yes & $.01(2.714)$ & .257 & No & Ns \\
\hline Ownership disadvantages & 14 & & & & & & \\
\hline Large and small & & .256 & No & Ns & .268 & No & Ns \\
\hline Large and medium & & .753 & Yes & $.01(3.964)$ & .182 & No & Ns \\
\hline Medium and small & & .010 & No & Ns & .128 & No & Ns \\
\hline
\end{tabular}

Notes: Large STCC (more than 500 employees), Medium STCC (200-500 employees) and Small STCC (less than 200 employees); $n$ is the number of factors for ownership advantages and disadvantages; $R_{S}$ is the Spearman's coefficient of rank correlation; computed t-statistics in parenthesis; Ns means 'not significant'.

means that specialized STCCs and diversified STCCs viewed the ranking of all their ownership advantages vis-à-vis ASEAN contractors differently.

The views of managers of STCCs of the ranking of all ownership advantages and disadvantages, according to organizational size (i.e. the number of employees) is presented in Table 7. Only large and small STCCs and medium and small STCCs varied in their views of the rankings of all their ownership disadvantages relative to other ASEAN contractors. The only exception is that both large and medium size STCCs viewed their ownership disadvantages $v i s-a ̀-v i s$ ASEAN contractors quite similarly (i.e. $\mathrm{R}_{\mathrm{S}}$ of $75.3 \%$ ). In other words, there was substantial positive correlation in the position of the rankings given to the 14 ownership disadvantage factors (as identified in Table 2), relative to other ASEAN contractors, by managers of medium and large size STCCs. On the other hand, generally all the STCCs (by size) varied in their view of the ranking of all the 14 ownership disadvantages relative to non-ASEAN contractors.
There was no significant difference in the views of managers of STCCs of the ranking of all ownership advantages vis-à-vis ASEAN contractors regardless of the number of years of international construction experience. Thus, to a certain extent, international age of STCCs was not a factor that varied the relative importance of the rankings of the 27 ownership advantages of STCCs relative to other ASEAN contractors. However, mixed results were observed with regard to the ranking of all ownership disadvantages by STCCs with various years of international construction experience (Table 8).

There was significant positive correlation of the rankings of all ownership advantages and all ownership disadvantages of STCCs vis-à-vis ASEAN contractors by managers of STCCs with a large number of permanent offices overseas and those with either a few or moderate number of permanent offices overseas (Table 9). Thus, the more internationally established STCCs tend to view the ranking order of their ownership advantages and

Table 8 Test of significance of variation in ranking of all ownership factors, Test of Hypothesis by age (years of international construction), $\mathrm{H}_{\mathrm{o}}$ : $\mathrm{R}_{\mathrm{S}}\left(\mathrm{FSCV}_{\mathrm{ijk}}\right)=0$, where $\mathrm{i}=$ (young; intermediate; mature); $\mathrm{j}=$ (years of international construction); $\mathrm{k}=$ (ASEAN and Non-ASEAN)

\begin{tabular}{|c|c|c|c|c|c|c|c|}
\hline \multirow[t]{2}{*}{ Ownership factors } & \multirow[t]{2}{*}{$n$} & \multicolumn{3}{|c|}{ ASEAN contractors } & \multicolumn{3}{|c|}{ Non-ASEAN contractors } \\
\hline & & $\mathrm{R}_{\mathrm{S}}$ & Reject $\mathrm{H}_{\mathrm{o}}$ ? & Significance level & $\mathrm{R}_{\mathrm{S}}$ & Reject $\mathrm{H}_{\mathrm{o}}$ ? & Significance level \\
\hline Ownership advantages & 27 & & & & & & \\
\hline Young and mature & & .362 & Yes & $.05(1.942)$ & .149 & No & Ns \\
\hline Young and intermediate & & .596 & Yes & $.01(3.711)$ & -.174 & No & Ns \\
\hline Intermediate and mature & & .381 & Yes & $.05(2.060)$ & .357 & Yes & $.05(1.911)$ \\
\hline Ownership disadvantages & 14 & & & & & & \\
\hline Young and mature & & -.078 & No & Ns & .549 & Yes & $.05(2.275)$ \\
\hline Young and intermediate & & -.046 & No & Ns & .317 & No & Ns \\
\hline Intermediate and mature & & .488 & Yes & $.05(1.937)$ & .052 & No & Ns \\
\hline
\end{tabular}

Notes: Age or years of international construction experience (Young means 1 to 10 years; intermediate means 11 to 20 years; and mature means more than 20 years); $n$ is the number of factors for ownership advantages and disadvantages; $\mathrm{R}_{\mathrm{S}}$ is the Spearman's coefficient of rank correlation; computed t-statistics in parenthesis; and Ns means 'not significant'. 
Table 9 Test of significance of variation in ranking of all ownership factors, Test of Hypothesis by multinationality, $\mathrm{H}_{\mathrm{o}}$ : $\mathrm{R}_{\mathrm{S}}$ $\left(\mathrm{FSCV}_{\mathrm{ijk}}\right)=0$, where $\mathrm{i}=($ large, moderate, few $) ; \mathrm{j}=$ (permanent offices overseas); $\mathrm{k}=($ ASEAN/Non-ASEAN)

\begin{tabular}{|c|c|c|c|c|c|c|c|}
\hline \multirow[t]{2}{*}{ Ownership factors } & \multirow[t]{2}{*}{$n$} & \multicolumn{3}{|c|}{ ASEAN contractors } & \multicolumn{3}{|c|}{ Non-ASEAN contractors } \\
\hline & & $\mathrm{R}_{\mathrm{S}}$ & Reject $\mathrm{H}_{\mathrm{o}}$ ? & Significance level & $\mathrm{R}_{\mathrm{S}}$ & Reject $\mathrm{H}_{\mathrm{o}}$ ? & Significance level \\
\hline Ownership advantages & 27 & & & & & & \\
\hline Large and few & & .427 & Yes & $.05(2.361)$ & .013 & No & Ns \\
\hline Large and moderate & & .510 & Yes & $.01(2.965)$ & -.390 & Yes & $.05(-2.118)$ \\
\hline Moderate and few & & .283 & No & Ns & .039 & No & Ns \\
\hline Ownership disadvantages & 14 & & & & & & \\
\hline Large and few & & .588 & Yes & $.05(2.518)$ & .211 & No & Ns \\
\hline Large and moderate & & .478 & Yes & $.05(1.885)$ & .460 & Yes & $.05(1.795)$ \\
\hline Moderate and few & & .423 & No & Ns & .725 & Yes & $.01(3.646)$ \\
\hline
\end{tabular}

Notes: Permanent offices overseas (large means more than 10 permanent offices; moderate means 6 to 10 permanent offices, and few means 1 to 5 permanent offices overseas); $n$ is the number of factors for ownership advantages and disadvantages; $R_{S}$ is the Spearman's coefficient of rank correlation; computed t-statistics in parenthesis; and Ns means 'not significant'.

Table 10 Test of significance of variation in ranking of all ownership factors, Test of Hypothesis for specialized and diversified STCCs, $\mathrm{H}_{\mathrm{o}}$ : $\mathrm{R}_{\mathrm{S}}\left(\mathrm{FSCV}_{\mathrm{ijk}}\right)=0$, where $\mathrm{i}=$ (specialized; diversified STCC); $\mathrm{j}=$ (Sector served by STCC); $\mathrm{k}=($ ASEAN or Non-ASEAN)

\begin{tabular}{|c|c|c|c|c|c|c|c|}
\hline \multirow[t]{2}{*}{ Ownership factors } & \multirow[t]{2}{*}{$n$} & \multicolumn{3}{|c|}{ ASEAN contractors } & \multicolumn{3}{|c|}{ Non-ASEAN contractors } \\
\hline & & $\mathrm{R}_{\mathrm{S}}$ & Reject $\mathrm{H}_{\mathrm{o}}$ ? & Significance level & $\mathrm{R}_{S}$ & Reject $\mathrm{H}_{\mathrm{o}}$ ? & Significance level \\
\hline Ownership advantages & 27 & & & & & & \\
\hline Specialized and diversified & & .720 & Yes & $.01(5.188)$ & .073 & No & Ns \\
\hline Ownership disadvantages & 14 & & & & & & \\
\hline Specialized and diversified & & .410 & No & Ns & .390 & No & Ns \\
\hline
\end{tabular}

Notes: Specialized STCC (mainly focused in one area of construction service overseas); diversified STCC (offering a combination of construction services overseas); $n$ is the number of factors for ownership advantages and disadvantages; $R_{S}$ is the Spearman's coefficient of rank correlation; computed t-statistics in parenthesis; and Ns means 'not significant'.

disadvantages relative to other ASEAN contractors quite similarly. With regard to non-ASEAN contractors, there was a relatively high positive correlation of the rankings of all ownership disadvantages of STCCs by managers of STCCs with moderate and little number of permanent offices overseas (Table 9).

Table 10 shows the test of significance of the views of managers according to diversified and specialized STCCs of the ranking of all ownership factors. Relatively high positive correlation of the rankings of all ownership advantages vis-à-vis ASEAN contractors is given by both specialized and diversified STCCs. On the other hand, the views of managers of both specialized and diversified STCCs of their ownership disadvantages varied significantly compared to both ASEAN and non-ASEAN contractors.

\section{Conclusion}

The role of ownership advantage factors in international construction has been comprehensively studied and identified in the literature by Seymour (1987), Mansfield (1988) and Nachum (1999). For example, Seymour (1987) showed that UK-based international contractors derive their most important ownership advantages from four factors, relative to indigenous contractors in the Middle East. These factors are: (1) superior technical knowledge, (2) greater experience in overseas operations, (3) management expertise and (4) good reputation.

This present research had almost similar results regarding the ownership advantage factors of STCCs compared with the findings of Seymour (1987). The findings (see Table 1) were that STCCs identified their most important ownership advantage factors relative to other ASEAN contractors as coming from: (1) information, knowledge, technology and R\&D capability; (2) firm's name and reputation; and (3) management and organizational capability. However, the greater experience in international operations - also identified by Nachum (1999) - was not identified by STCCs as one of their most important ownership advantages. The reason for this difference is that relative to the UK-based international contractors or other more established international contractors (e.g. Japanese or Korean), the Singapore contractors engaged in international construction operations are relatively younger in terms of the number of years of international construction experience. The findings of Mansfield (1988) regarding the main ownership advantage factors as coming from 
technical expertise and differentiating abilities were likewise supported by this research.

Besides having a good name and reputation among their clients in the ASEAN market and China, STCCs viewed their other most important ownership advantage factors relative to non-ASEAN contractors in the construction markets in the ASEAN region and China to include both their human resource management and business development capabilities (see Table 1). This finding does not tie in completely with the findings of Seymour (1987). One probable reason for this difference is because Singapore contractors belong to the ASEAN region, whereas UK-based international contractors in the study of Seymour (1987) were from outside the Middle East region. Thus, as expected and confirmed, STCCs would identify one of their ownership advantage factors as that of having a good knowledge of the people and the business practice of the region they come from.

One of the ownership disadvantage factors identified in the literature as contributing to the construction corporation's weakness is the reducing demand for construction services in their home market (Mansfield, 1988). STCCs likewise viewed the reducing home market demand for construction services as their most important ownership disadvantage factors or threat compared with other ASEAN contractors. This finding was not in agreement with the findings of Seymour (1987) who viewed the most important ownership disadvantage of UK-based contractors as coming from the protectionist policies and attitudes of Arab governments. One probable reason for this difference concerning reducing home market demand is the size of the construction market of Singapore, as being relatively a lot smaller than that of the UK. However, in terms of the two other ownership disadvantages - the lower costs of indigenous contractors and their better knowledge of their country and clients - these were similarly identified in this research, as was in the case of Seymour (1987), as one of the more important ranked ownership disadvantages. The protectionist government policies of host countries in the ASEAN region was identified as a sixth ranked ownership disadvantage factor by STCCs among the 14 ownership disadvantage factors ranked by respondents. The STCCs' view on protectionism in the ASEAN construction market as being relatively less than the UK-based contractor's view of protectionism in the Middle East could be due to the UK-based contractor's being of a more diverse cultural and geographic situation than Singapore contractors in the ASEAN market.

Relative to the more advanced international contractors operating in the construction market in the ASEAN region and China, STCCs viewed their ownership disadvantage to be coming from their relatively smaller size. This finding varied with the results on ownership disadvantages of UK-based international contractors relative to non-UK based international contractors operating in foreign construction markets (Seymour, 1987; Mansfield, 1988). Thus, relative to international contractors (e.g. South Korea, USA, UK or Japan), STCCs have a significant size disadvantage with reference to certain project types.

\section{Acknowledgements}

The authors would like to acknowledge the very helpful and constructive comments given by the referees.

\section{References}

Abdul-Aziz, A. (1995) Examination of the eclectic paradigm as applied to international contracting - with emphasis on the internalization dimension. Engineering, Construction and Architectural Management, 2(2), 105-20.

BCA (1999) Export of construction and construction-related services in 1998, by Chan Wing Wei. In Construction Economics Report Third Quarter 1999, Economics \& Resources Department, Building and Construction Authority, Singapore, pp. 8-17.

Cantwell, J. (1991). A survey of theories of international production. In Pitelis, C.N. and Sugden, R. (eds), The Nature of the Transnational Firm, Routledge, London, pp. 16-63.

CIDB (various issues) Annual Report 1985-1998, Construction Industry Development Board, Singapore.

Conover, W.J. and Iman, R.L. (1983) Introduction to Modern Business Statistics, John Wiley \& Sons, New York.

Dunning, J.H. (1977) Trade, location of economic activity and the MNE: a search for an eclectic approach. In Ohlin, B., Hesselborn, P. and Wijkman, P. M. (eds), The International Allocation of Economic Activity, The Macmillan Press Ltd, London, pp. 395-431.

Dunning, J.H. (1981) Explaining the international direct investment position of countries: towards a dynamic or developmental approach. Weltwirtschaftliches Archiv (Review of World Economics, Journal of the Kiel Institute of World Economics), 117(1), 30-64.

Dunning, J.H. (1983) Changes in the level and structure of international production: the last one hundred years. In Casson, M. (ed.), The Growth of International Business, George Allen \& Unwin Ltd, London, pp. 84-139.

Dunning, J.H. (1985) Introduction. In Dunning, J.H. (ed.), Multinational Enterprises, Economic Structure and International Competitiveness, Wiley, New York, pp. 1-11.

Dunning, J.H. (1988a) Explaining International Production, Unwin Hyman Ltd, London.

Dunning, J.H. (1988b) Multinationals, Technology and Competitiveness, Unwin Hyman Ltd, London.

Dunning, J.H. (1990) The globalization of firms and the competitiveness of countries. In Dunning, J.H., Kogut, B. and Blomstrom, M. (eds), Globalization of Firms and the Competitiveness of Nations, Institute of Economic Research, Lund University, Lund, pp. 9-57. 
Dunning, J.H. (1993) Multinational Enterprises and the Global Economy, Addison-Wesley Publishing Company, Wokingham.

Dunning, J.H. (1995) Reappraising the eclectic paradigm in an age of alliance capitalism. Fournal of International Business Studies, 26(3), 461-91.

Dunning, J.H. (1997) The economic theory of the firm as the basis for a 'core' theory of international production. In Islam, I. and Shepherd, W. (eds), Current Issues in International Business. Edward Elgar Publishing, Cheltenham, pp. $60-8$.

Dunning, J.H. (1998a) American Investment in British Manufacturing Industry, revised and updated edition, Routledge, New York.

Dunning, J.H. (1998b) The changing geography of foreign direct investment. In Kumar, N. (ed.), Globalization, Foreign Direct Investment and Technology Transfers Impact on and Prospects for Developing Countries, Routledge in association with the United Nations University Press, New York, pp. 43-89.

Dunning, J.H. (1998c) Does ownership really matter in a globalizing economy? In Woodward, D. and Nigh, D. (eds), Foreign Ownership and the Consequences of Direct Investment in the United States: Beyond Us and Them, Quorum Books, Westport, CT, pp. 27-42.

Dunning, J.H. and Kundu, S.K. (1995) The internationalization of the hotel industry - some new findings from a field study. Management International Review, 35(2), 101-33.

Gray, H.P. (1999). Global Economic Involvement: A Synthesis of Modern International Economics, HandelshØjskolens Forlag, Copenhagen Business School Press, Copenhagen.

Hymer, S. (1976). The International Operations of National Firms: A Study of Direct Foreign Investment, The MIT Press, Cambridge, MA.

Itaki, M. (1991). A critical assessment of the eclectic theory of the multinational enterprise. Fournal of International Business Studies, 22(3), 445-60.
Lall, S. (1993). Monopolistic Advantages and Foreign Involvement by US Manufacturing Industry. In Dunning, J.H. (ed.), The Theory of Transnational Corporations, Vol. 1, The United Nations Library on Transnational Corporations, Routledge, London, pp. 289-311.

Lundgren, N. (1977). Comment on chapter by J.H. Dunning. In Ohlin, B., Hesselborn, P. and Wijkman, P.M. (eds), The International Allocation of Economic Activity, The Macmillan Press Ltd, London, pp. 419-25.

Mansfield, N. (1988) Assessment of strengths in the UK inter-national construction sector. Project Management, 6(3), 141-6.

Mason, R.D., Lind, D.A. and Marchal, W.G. (1999) Statistical Techniques in Business and Economics, Tenth Edition (International), McGraw-Hill, New York.

Nachum, L. (1999) The Origins of the International Competitiveness of Firms, Edward Elgar, Cheltenham.

Newbold, P. (1991) Statistics for Business and Economics, 3rd edn, Prentice Hall, New Jersey.

Seymour, H. (1987) The Multinational Construction Industry, Croom Helm, London.

Singapore Department of Statistics (1997) Singapore's Investment Abroad, 1994-1995, Ministry of Trade \& Industry, Singapore.

Singapore Department of Statistics (2000) Singapore's Investment Abroad, 1997-1998, Ministry of Trade \& Industry, Singapore.

Tan, W. (1995) Research Methods in Real Estate and Construction, School of Building and Estate Management (SBEM) Textbook Series, School of Building and Estate Management, National University of Singapore, Singapore.

\section{Note}

1. The SPSS (Version 10) software was used to compute $\mathrm{R}_{\mathrm{S}}$ and to test its significance. 